\title{
Baseline QRS Duration Associates with Cardiac Recovery in Patients with Continuous-Flow Left Ventricular Assist Device Implantation
}

Muhammad S. Khan PhD ${ }^{1 \dagger}$; Christos P. Kyriakopoulos MD 1,2t; losif Taleb MD ${ }^{1,2}$; Elizabeth Dranow PhD ${ }^{2}$; Monte Scott MD ${ }^{2}$; Ravi Ranjan MD PhD 1,2,3; Michael Yin MD

2; Eleni Tseliou MD PhD 2; Rami Alharethi MD 4; William Caine MD 4; Robin M. Shaw MD PhD 1,2; Craig H. Selzman MD 1,5; Stavros G. Drakos MD PhD 1,2,3**; Derek J. Dosdall $\operatorname{PhD} 1,2,3,5 *$

${ }^{1}$ Nora Eccles Harrison Cardiovascular Research and Training Institute, The University of Utah, Salt Lake City, UT.

${ }^{2}$ Division of Cardiovascular Medicine, Department of Internal Medicine, University of Utah Health \& School of Medicine, Salt Lake City, UT.

${ }^{3}$ Department of Biomedical Engineering, The University of Utah, Salt Lake City, UT.

${ }^{4}$ Cardiovascular Department, Intermountain Medical Center, Salt Lake City, UT.

${ }^{5}$ Division of Cardiothoracic Surgery, Department of Surgery, University of Utah Health \& School of Medicine, Salt Lake City, UT.

† Authors contributed equally

\section{Corresponding Authors:}

** Stavros G. Drakos, MD, PhD, FACC

Professor of Medicine, Co-Director, Heart Failure and Transplant Section Medical Director, Cardiac Mechanical Support Program 
Cardiovascular Research Director - Division of CV Medicine

The University of Utah - Health

30 North Medical Drive, Salt Lake City, UT 84132

Tel.: +1-801-585-2340 Fax: +1-801-581-0701

Email: stavros.drakos@hsc.utah.edu

\section{${ }^{*}$ Dr. Derek J. Dosdall, PhD, FHRS, FAHA}

Associate Professor of Surgery, Division of Cardiothoracic Surgery

Cardiovascular Research and Training Institute

The University of Utah - Health

95 South 2000 East, Salt Lake City, UT 84112

Off: $+1-801-587-2036$

Email: derek.dosdall@utah.edu 
BACKGROUND: In chronic heart failure (HF) patients supported with continuous-flow left ventricular assist device (CF-LVAD), we aimed to assess the clinical association of baseline QRS duration (QRSd) with post-LVAD cardiac recovery, and its correlation with pre- to post-LVAD change in left ventricular ejection fraction (LVEF) and left ventricular end-diastolic diameter (LVEDD).

METHODS: Chronic HF patients $(n=402)$ undergoing CF-LVAD implantation were prospectively enrolled, at one of the centers comprising the U.T.A.H. (Utah Transplant Affiliated Hospitals) consortium. After excluding patients with acute HF etiologies, hypertrophic or infiltrative cardiomyopathy, and/or inadequate post-LVAD follow up $(<3$ months), 315 patients were included in the study. Cardiac recovery was defined as LVEF $\geq 40 \%$ and LVEDD $<6 \mathrm{~cm}$ within 12 months post-LVAD implantation. Patients fulfilling this condition were termed as responders $(R)$ and results were compared with non-responders (NR).

RESULTS: Thirty-five patients (11\%) achieved 'R' criteria, and exhibited a 15\% shorter QRSd compared to 'NR' $(123 \pm 37$ ms vs $145 \pm 36$ ms; $p<0.001)$. A univariate analysis identified association of baseline QRSd with post-LVAD cardiac recovery (OR:0.986, 95\% Cl:0.976-0.996, p<0.001). In a multivariate logistic regression model, after adjusting for duration of HF (OR:0.990, 95\% Cl:0.983-0.997, $\mathrm{p}=0.006)$ and gender (OR:0.388, 95\% Cl:0.160-0.943, p=0.037), pre-LVAD QRSd exhibited a significant association with post-LVAD cardiac structural and functional improvement (OR:0.987, $95 \% \mathrm{Cl}: 0.977-0.998, \mathrm{p}=0.027)$ and the predictive model showed a c-statistic of 0.73 with 
medRxiv preprint doi: https://doi.org/10.1101/2021.09.21.21263287; this version posted September 23, 2021. The copyright holder for this preprint (which was not certified by peer review) is the author/funder, who has granted medRxiv a license to display the preprint in perpetuity. It is made available under a CC-BY-NC-ND 4.0 International license .

$p<0.001$. The correlations for baseline QRSd with pre- to post-LVAD change in LVEF and LVEDD were also investigated in 'R' and 'NR' groups.

CONCLUSION: Chronic advanced HF patients with a shorter baseline QRSd exhibit an increased potential for cardiac recovery after LVAD support.

Keywords: QRS duration; LVAD; cardiac recovery; LVEF; LVEDD; electrical remodeling. 


\section{INTRODUCTION}

In patients with advanced heart failure (HF) refractory to medical therapy, continuousflow (CF) left ventricular (LV) assist devices (LVADs) have been used as a bridge to transplantation, ${ }^{1,2}$ as destination therapy, ${ }^{3}$ as a bridge to transplant candidacy, and/or as a bridge to recovery. ${ }^{4,5}$ The number of LVAD implantations has continued to grow in the US in comparison with the number of heart transplantations. ${ }^{6,7}$ While left ventricular ejection fraction (LVEF) during mechanical unloading is used to identify patients achieving cardiac recovery, it has showed no predictive value prior to LVAD implantation. ${ }^{8} \mathrm{LV}$ torsion has been found to play a pivotal role in facilitating the homogenous distribution of myocardial forces during systole. ${ }^{9}$ Clinical studies in chronic HF patients have associated LV rotational dynamics with the degree of remodeling and the extension of myocardial fibrosis. ${ }^{10,11}$ In addition, LV global longitudinal strain has been previously studied and correlated with the extent of myocardial fibrosis in patients with advanced HF. ${ }^{12,13}$

Previous studies have focused on a prolonged QRS duration (QRSd) that appears common in patients with reduced LVEF and were hospitalized for HF management. ${ }^{14-16}$ Further, the impact of LVAD unloading on the electrical properties (QRS, QT and QTc duration) of the failing heart has also been reported. ${ }^{17}$ In this study, we sought to examine whether baseline QRSd associates with post-LVAD cardiac recovery in chronic heart failure (CHF) patients undergoing LVAD implantation. We further demonstrate the correlations for baseline QRSd with pre- and post-LVAD LVEF and LVEDD in LVAD patients, and compared the data of those who showed a 
successful cardiac recovery with those who did not show recovery within 12 months of LVAD support. Finally, in addition to univariate and bivariate analyses, a multivariate logistic regression model is reported including other clinical parameters to find whether the baseline QRSd is independently associated with post-LVAD cardiac recovery.

\section{METHODS}

\section{Study Population}

Advanced cardiomyopathy patients $(n=402)$ undergoing LVAD implantation at one of the institutions comprising the Utah Transplant Affiliated Hospitals (U.T.A.H.) Cardiac Transplant Program (i.e. University of Utah Health, Intermountain Medical Center, and George E. Wahlen Veterans Affairs Medical Center) were prospectively enrolled. The study was approved by the Institute Review Board (IRB) -The University of Utah, Salt Lake City, UT 84112. Ethical approval was given, and the patients were prospectively enrolled. Informed consent was obtained under the IRB 30622 - "Effects of Mechanical Unloading on Myocardial Function and Structure in Humans study." Acute HF etiologies, hypertrophic or infiltrative cardiomyopathy, baseline LVEF $\geq 40 \%$, and inadequate postLVAD follow up ( $<3$ months) were the exclusion criteria. Our final study cohort included a total of 315 patients [56 \pm 15 years old, $267(85 \%)$ male] as shown in Fig. 1. The patients' long-term medications regimen before LVAD implantation included ß-blockers, angiotensin-converting enzyme inhibitors (ACEI), angiotensin II receptor blockers (ARB), aldosterone antagonists, and diuretics. About $71 \%$ patients were NYHA class IV. 
Implanted devices were HeartMate $\mathrm{II}^{\mathrm{TM}}(\mathrm{n}=121)$, HeartMate $3^{\mathrm{TM}}(\mathrm{n}=17)$, HeartWare ${ }^{\mathrm{TM}}$ $(n=156)$ and others $(n=21)$.

\section{LVAD-induced Cardiac Recovery Definition}

LVAD-induced cardiac recovery was defined as an LVEF $\geq 40 \%$ and LVEDD $<6 \mathrm{~cm}$ within 12 months post-LVAD implantation. Patients fulfilling the above criteria were termed responders $(R)(n=35)$ with their counterparts not achieving significant cardiac structural and functional improvement following LVAD implantation, constituting the nonresponders (NR) group $(n=280)$.

\section{Data Collection}

Demographic, medication, laboratory, hemodynamic and electrocardiographic data were collected within 1 week prior to LVAD implantation. Transthoracic echocardiograms were performed within 2 weeks preceding LVAD implant, and then serially at months $1,2,3,4,6,9$, and 12 after implantation, using a protocol developed and tested at the Utah Cardiac Recovery Program. ${ }^{18}$ Complete 2-dimensional, M-mode, and Doppler images were recorded from standard views in accordance with current American Society of Echocardiography guidelines. ${ }^{19}$ Last available reported LVEF and LVEDD values within 1-year post-LVAD implant were used to assess cardiac recovery.

\section{Statistical Analysis}

Continuous variables are expressed as mean \pm standard deviation and were compared using unpaired t-test. Categorical variables are expressed as counts and percentages 
and were compared using chi-square test. Covariates remaining at the last step were included in the multivariable model to evaluate baseline QRS as an independent predictor for post-LVAD cardiac recovery. The presence of collinearity among candidate covariates was assessed with the variance inflation factor diagnostic. ${ }^{20} \mathrm{~A}$ bootstrap inclusion fraction (BIF) was calculated for each potential predictor, defined as the percentage of time that each variable would be retained in the model as a significant predictor in 1000 bootstrap resamples, in which the backwards elimination variable selection is repeated. ${ }^{21}$ Variables with $\mathrm{BIFs}<50 \%$ were dropped from the model as unreliable, as these would not likely remain significant predictors in external data sets. A $p$-value $<0.10$ was used to screen covariates for inclusion in the multivariate analysis. Receiver-operator-characteristics curve analysis was performed to determine the accuracy of pre-LVAD QRSd along with other potential variables to predict post-LVAD cardiac recovery. Based on a previously reported method, ${ }^{22}$ a truncation approach was also applied to overcome the missing data, equipment limit resolution and to remove outliers in both the ' $R$ ' and 'NR' groups. All significance tests were 2-tailed, and $p<0.05$ was considered statistically significant. Statistical analyses were performed using Stata 16.0. ${ }^{23}$

\section{RESULTS}

Among 315 chronic HF patients included in the analysis, 35 patients achieved cardiac recovery while on LVAD support $(R)$. We summarized the baseline clinical characteristics, medications, laboratory results, hemodynamic and echocardiography 
parameters of 'R' and 'NR' in Table 1. Following sections will elaborate on the differences between the two groups of LVAD patients.

\section{Baseline Characteristics of LVAD Patients with Cardiac Recovery}

Among many baseline and clinical parameters outlined in Table 1, age, body surface area (BSA), previous thoracotomy, ischemic HF etiology and pre-LVAD HF duration were significantly different in the 'R' and 'NR' groups. For example, the group of patients who did not respond to LVAD support were older than those who responded within 12 months of LVAD support ( $57 \pm 14$ vs. $49 \pm 20$ years, $p=0.014$ ), and also pre-LVAD BSA of 'NR' group was higher $\left(2.05 \pm 0.25\right.$ vs. $\left.1.96 \pm 0.23 \mathrm{~m}^{2}, p=0.021\right)$ in comparison to the ' $R$ ' group. Further, in comparison to the ' $R$ ' group, patients in the 'NR' group had a significantly longer HF duration ( $96 \pm 87$ vs. $44 \pm 53$ months, $p<0.001)$ with a history of previous thoracotomy $(p=0.014)$ and an ischemic HF etiology $(p=0.019)$ as detailed in

\section{Table 1.}

Regarding laboratory results, baseline B-type natriuretic peptide (BNP) level in the 'R' group was significantly higher in comparison to the 'NR' group $(1902 \pm 1380$ $\mathrm{pg} / \mathrm{mL}$ vs. $1330 \pm 1171, p=0.039$ ). Finally, pre-LVAD LVEDD and LVESD of 'R' group LVAD patients were significantly lower as compared to 'NR' group and reported as $6.4 \pm 0.9$ vs. $6.8 \pm 1.0 \mathrm{~cm}(p=0.040)$ and $6.0 \pm 0.9$ vs. $6.2 \pm 1.1 \mathrm{~cm}(p=0.048)$, respectively. Details of other significant / non-significant clinical, laboratory, hemodynamic and echocardiographic parameters are listed in Table 1.

\section{Baseline QRSd in LVAD Patients}


The mean baseline QRSd of the total study population was $143 \pm 37 \mathrm{~ms}$. Pre-LVAD QRSd in the 'R' group was $14.5 \%$ shorter than the duration reported in the 'NR' group (123 \pm 37 ms vs. $145 \pm 36 \mathrm{~ms}$, respectively, $p<0.001)$, as shown in Fig. 2. Interestingly, LVEF did not differ significantly between the 'R' and 'NR' groups before LVAD implantation ( $17.8 \pm 7.5$ vs. $18.1 \pm 6.6 \%, p=0.776)$. Based on univariate logistic regression (Table 2), pre-LVAD QRSd shows a significant association with post-LVAD cardiac recovery in LVAD patients (OR: 0.983, 95\% Cl: 0.972-0.993, p<0.001).

\section{Correlation of Baseline QRSd with Pre- and Post-LVAD LVEF and LVEDD in LVAD Patients}

Before LVAD implant, as shown in Fig. 3a, there is a weak and non-significant correlation between QRSd and pre-LVAD LVEF in LVAD patients $(r=-0.04, p=0.494)$. Unlike LVEF, pre-LVAD LVEDD exhibits a significant correlation with baseline QRSd as shown in Fig. 3d $(r=0.24, p<0.01)$. After CF-LVAD support, the baseline QRSd shows a significant correlation with post-LVAD LVEF $(r=-0.20, p<0.001)$ and similarly with pre- to post-LVAD LVEF change $(r=-0.19, p<0.001)$, as shown in Fig. $\mathbf{3 b}$ and Fig. 3c, respectively. Nevertheless, baseline QRSd correlates non-significantly with post-LVAD LVEDD ( $r=0.07, p=0.208)$ and pre- to post-LVAD LVEDD change $(r=-0.01, p=0.966)$ as shown in Fig. 3e and $\mathbf{2 f}$, respectively.

Correlation of Baseline QRSd with Pre- and Post-LVAD LVEF in Responders and Non-Responders 
The relationship of baseline QRSd with LVEF before and after LVAD support, and preto post-LVAD change in LVEF in the 'R' group was investigated (Top row) as shown in Fig. 4 and the results were compared with the 'NR' group (Bottom row). As shown in Fig. 4a, the 'R' group shows a significant improvement in LVEF (18 \pm 8 vs. $46 \pm 7 \%$, $p<0.001)$ before and after LVAD implantation. However, the baseline QRSd is poorly and non-significantly correlated with pre-LVAD LVEF $(r=0.15, p=0.386)$, post-LVAD $\operatorname{LVEF}(r=-0.15, p=0.386)$ and $\Delta \operatorname{LVEF}(r=-0.22, p=0.205)$ as shown in Fig. 4b, 3c , and 3d, respectively. Though after CF-LVAD support, the change in LVEF in 'NR' group is significant as shown in Fig. 4 e $(18 \pm 7$ vs. $22 \pm 6 \%, p<0.001)$, this group did not fulfill the criteria for post-LVAD cardiac recovery. Similarly, in the 'NR' group, the baseline QRSd is poorly and non-significantly related with pre-LVAD LVEF $(r=-0.07, p=0.250)$, postLVAD LVEF $(r=-0.07, p=0.257)$ and $\Delta \operatorname{LVEF}(r=-0.10, p=0.104)$ as shown in Fig. $\mathbf{4 f}, \mathbf{3 g}$ and $3 \mathrm{~h}$, respectively.

\section{Correlation of Baseline QRSd with Pre- and Post-LVAD LVEDD Change in}

\section{Responders and Non-Responders}

The impact of baseline QRSd on pre-LVAD LVEDD, post-LVAD LVEDD and $\triangle$ LVEDD (pre- to post-LVAD change in LVEDD) in the 'R' group (Top row) was studied as shown in Fig. 5, and compared with 'NR' group (Bottom row). As shown in Fig. 5a and Fig. 5e, both groups ('R' and 'NR') show a significant improvement in post-LVAD LVEDD in comparison to their pre-LVAD LVEDD measures, respectively. Specifically, the ' $R$ ' group exhibits a $28 \%$ improvement in LVEDD following LVAD implant $(6.4 \pm 0.9$ vs. 4.6 $\pm 0.6 \mathrm{~cm}, p<0.001)$. However, there was no correlation of the baseline QRSd with the 
pre- and post-LVAD LVEDD, as shown in Fig. $5 \mathbf{b}(r=0.19, p=0.268)$ and Fig. $5 \mathbf{c}(r=0.19$, $p=0.273)$, respectively. Similarly, in the ' $R$ ' group, the pre- to post-LVAD change in LVEDD is not correlated with baseline QRSd as shown in Fig. $\mathbf{5 d}(r=0.06, p=0.724)$. On the other side, in the 'NR' group, a $12 \%$ improvement in LVEDD is reported following LVAD implant $(6.8 \pm 1.0$ vs. $6.0 \pm 1.0 \mathrm{~cm}, \mathrm{p}=\mathrm{p}<0.001)$ as shown in Fig. $\mathbf{5 e}$, whereas their baseline QRSd is poorly and non-significantly correlated with pre- to post-LVAD LVEDD change, as shown in Fig. $5 \mathrm{~h}(\mathrm{r}=-0.06, \mathrm{p}=0.315)$.

\section{Bivariate and Multivariate Analysis}

In the bivariate models (Table 3), baseline QRSd is significantly associated with cardiac recovery after adjusting for age (OR: $0.983,95 \% \mathrm{Cl}: 0.972-0.993, p=0.001)$, BSA (OR: 0.222, 95\% Cl: $0.049-0.946, p=0.046)$, previous thoracotomy (OR: $0.298,95 \% \mathrm{Cl}$ : 0.069-0.878, $p=0.053$ ), ischemic HF etiology (OR: $0.430,95 \% \mathrm{Cl}: 0.175-0.949$, $p=0.047$, and BNP (OR: 1.000, 95\% Cl: 1.000-1.001, $p=0.005)$. No other variables are associated with cardiac recovery in bivariate models when adjusted for baseline QRSd, though the baseline QRSd remained significant in those models (Table 3).

The multivariate model (Table 4) with three parameters including baseline QRSd (OR: $0.987,95 \% \mathrm{Cl}: 0.977-0.998, p=0.027$ ), duration of HF (OR: $0.990,95 \% \mathrm{Cl}: 0.983-$ 0.997, $p=0.006)$ and gender: male (OR: $0.388,95 \% \mathrm{Cl}: 0.160-0.943, p=0.037)$ shows association for predicting post-LVAD cardiac recovery in LVAD patients with an accuracy of $0.73(p<0.0001)$ as shown in Fig. 6. 


\section{DISCUSSION}

In chronic HF patients undergoing LVAD implantation, baseline QRSd was found to be associated with post-LVAD cardiac recovery within 12-months post-LVAD implantation. The pre-LVAD QRSd in the 'R' group was significantly shorter (15\%) in comparison to the 'NR' group. It is noteworthy that patients who experienced cardiac recovery following LVAD implantation had a baseline LVEF similar to those who did not show post-LVAD cardiac recovery (Table 1). A comparable LVEF in the two groups is also consistent with previous studies. , $^{8,18,24}$

Previous studies have identified non-ischemic HF etiology, younger age and LV torsional mechanics as independent predictors of cardiac recovery. ${ }^{9,25,26}$ In concordance to these findings, our univariate data analysis showed that LVAD patients who achieved cardiac recovery within 12-months after LVAD implant were also more likely to be younger, female patients with a history of non-ischemic cardiomyopathy . Additionally, in responders the time from the HF diagnosis to the implantation of the LVAD was significantly shorter, a previous thoracotomy was less common, and there was a trend towards significance for higher baseline BNP levels compared to non-responders.

Previous studies have focused on a prolonged QRSd that appears common in patients suffering from HF with reduced LVEF. ${ }^{14-16}$ These studies emphasized that a baseline QRSd above $\geq 120$ ms was associated with a significantly increased risk of death compared with a baseline QRSd $<120 \mathrm{~ms}$. Two prospective studies with 36 and 12 LVAD-supported patients, respectively, have previously investigated the QRS complex shortening at different time points during mechanical unloading. However, 
these studies did not explore an investigation of the effect of pre-LVAD QRSd on LVADinduced cardiac recovery. Similarly, another prospective study of 23 LVAD patients, investigated the trajectory of QRSd immediately prior to LVAD implantation, and subsequently early and late while on LVAD support ${ }^{27}$ Their findings did not focus on whether the pre-LVAD QRSd may predict the post-LVAD cardiac recovery in the same group of patients, instead they reported the comparison of baseline QRSd in LVAD patients $(n=23)$ with another 22 control patients undergoing coronary artery bypass grafting. None of these studies reported the relationship of pre-LVAD QRSd in LVAD patients to cardiac recovery. One of the potential reasons could be their small sample size.

Based on a meta-analysis, the effect of very low LVEF and prolonged QRSd on the mortality benefits of ICD therapy has been reported in the general HF population. ${ }^{30}$ Further, pre- and post-LVAD fragmented QRS complex was studied in 98 LVAD patients to seek its association with survival following LVAD implantation over a 30month follow-up period. ${ }^{28}$ Their results were based on the prevalence of fragmented QRS quantified at anterior, inferior and lateral territories. They did not distinguish the role of fragmented QRS as a predictor of cardiac recovery following LVAD support. The impact of baseline QRSd on pre- to post-LVAD change in LVEF has not been previously studied in CHF patients undergoing LVAD implantation, although the relation between fragmented QRS and LVEF has been discussed in HF patients. ${ }^{29} \mathrm{~S}$

Similarly, the impact of baseline QRSd on LVEDD before and after LVAD support in chronic HF patients has not been reported yet. A positive association between QRSd 
and LV size in patients with bundle branch block was discussed previously, ${ }^{31,32}$ and it has been suggested that LV size does not modify the effect of baseline QRSd and its association with outcomes following cardiac resynchronization therapy. ${ }^{33}$ In our study, we observed a significant correlation of baseline QRSd with pre-LVAD LVEDD and a non-significant correlation with post-LVAD LVEDD as shown in Fig. $\mathbf{3 d}$ and Fig. $\mathbf{2 e}$, respectively. At a first glance, this suggests that QRSd could play a vital role with preLVAD LVEDD in LVAD patients, however, the proposed scientific evidence is not true neither for the individuals who improved their cardiac structure and function while on LVAD support, (Fig. 4b) nor for those who did not (Fig. 4f). Compared to the 'NR' group that exhibited a $12 \%$ improvement in LVEDD, the 'R' group showed a $28 \%$ improvement from pre- to post-LVAD change in LVEDD, and these data indicate that QRSd may reflect the dimension and muscle mass of the LV and may be a useful indicator of LVAD-induced cardiac recovery.

\section{STUDY LIMITATIONS:}

The number of patients that fulfilled the criteria for post-LVAD cardiac recovery was relatively small $(n=35)$. Future studies with a larger sample size are warranted to further explore the role of LV electrical remodeling in LVAD-induced cardiac recovery. LVAD patients with bundle branch block should ideally be studied separately regarding their baseline QRSd and the cardiac recovery potential. Integrating pre-LVAD QRSd to previously reported pre-LVAD clinical and translational cardiac recovery predictors may 
provide a highly sensitive and patient-specific electro-mechanistic method for predicting cardiac structural and functional improvement after LVAD unloading.

\section{CONCLUSIONS:}

Baseline QRSd effectively identified a subset of advanced cardiomyopathy patients prone to improve their cardiac structure and function following LVAD support. It could serve as a useful clinical indicator to guide the implementation of systematic monitoring and treatment strategies to promote cardiac recovery in selected LVAD candidates. Future research is warranted to further explore the association of baseline electrocardiographic indices with LV structural changes during mechanical support. Finally, strategies to facilitate cardiac recovery should be encouraged in such patients with the ultimate goal of LVAD weaning.

Data availability statement: The datasets generated during and/or analyzed during the current study are available from the corresponding author on reasonable request.

Additional Information: Supplementary information is available for this paper in the supporting document attached to this file.

\section{References}

1. Holley CT, Harvey L, John R. Left ventricular assist devices as a bridge to cardiac transplantation. Journal of Thoracic Disease. 2014;6(8):1110-1119. 
2. Jakovljevic DG, Yacoub MH, Schueler S, MacGowan GA, Velicki L, Seferovic PM, Hothi S, Tzeng BH, Brodie DA, Birks E, Tan LB. Left Ventricular Assist Device as a Bridge to Recovery for Patients With Advanced Heart Failure. Journal of the American College of Cardiology. 2017;69(15):1924-1933.

3. Rose EA, Gelijns AC, Moskowitz AJ, Heitjan DF, Stevenson LW, Dembitsky W, Long JW, Ascheim DD, Tierney AR, Levitan RG, Watson JT, Ronan NS, Shapiro PA, Lazar RM, Miller LW, et al. Long-term use of a left ventricular assist device for end-stage heart failure. New England Journal of Medicine. 2001;345(20):14351443.

4. Stewart GC, Givertz MM. Mechanical circulatory support for advanced heart failure: Patients and technology in evolution. Circulation. 2012;125(10):13041315.

5. Patel CB, Alexander KM, Rogers JG. Mechanical circulatory support for advanced heart failure. Current Treatment Options in Cardiovascular Medicine. 2010;12(6):549-65.

6. Copeland JG, Smith RG, Arabia FA, Nolan PE, Sethi GK, Tsau PH, McClellan D, Slepian MJ. Cardiac replacement with a total artificial heart as a bridge to transplantation. New England Journal of Medicine. 2004;351(9):859-867.

7. Kirklin JK, Naftel DC, Pagani FD, Kormos RL, Stevenson LW, Blume ED, Myers SL, Miller MA, Baldwin JT, Young JB. Seventh INTERMACS annual report: 15,000 patients and counting. Journal of Heart and Lung Transplantation. 2015;34(12):1495-1504. 
8. Dandel M, Weng Y, Siniawski H, Stepanenko A, Krabatsch T, Potapov E, Lehmkuhl HB, Knosalla C, Hetzer R. Heart failure reversal by ventricular unloading in patients with chronic cardiomyopathy: Criteria for weaning from ventricular assist devices. European Heart Journal. 2011;32(9):1148-1160.

9. Bonios MJ, Koliopoulou A, Wever-Pinzon O, Taleb I, Stehlik J, Xu W, WeverPinzon J, Catino A, Kfoury AG, Horne BD, Nativi-Nicolau J, Adamopoulos SN, Fang JC, Selzman CH, Bax JJ, et al. Cardiac Rotational mechanics as a predictor of myocardial recovery in heart failure patients undergoing chronic mechanical circulatory support a pilot study. Circulation: Cardiovascular Imaging. 2018;11(4):e007117.

10. Popescu BA, Beladan CC, Călin A, Muraru D, Deleanu D, Roşca M, Ginghină C. Left ventricular remodelling and torsional dynamics in dilated cardiomyopathy: Reversed apical rotation as a marker of disease severity. European Journal of Heart Failure. 2009;11(10):945-951.

11. Taylor RJ, Umar F, Lin ELS, Ahmed A, Moody WE, Mazur W, Stegemann B, Townend JN, Steeds RP, Leyva F. Mechanical effects of left ventricular midwall fibrosis in non-ischemic cardiomyopathy. Journal of Cardiovascular Magnetic Resonance. 2016;18(1):1-8.

12. Cameli M, Mondillo S, Righini FM, Lisi M, Dokollari A, Lindqvist P, Maccherini M, Henein M. Left Ventricular Deformation and Myocardial Fibrosis in Patients With Advanced Heart Failure Requiring Transplantation. Journal of Cardiac Failure. 2016;22(11):901-907.

13. Bertini M, Ng ACT, Antoni ML, Nucifora G, Ewe SH, Auger D, Marsan NA, Schalij 
MJ, Bax JJ, Delgado V. Global longitudinal strain predicts long-term survival in patients with chronic ischemic cardiomyopathy. Circulation: Cardiovascular Imaging. 2012;5(3):383-391.

14. Kashani A, Barold SS. Significance of QRS complex duration in patients with heart failure. Journal of the American College of Cardiology. 2005;46(12):21832192.

15. Auricchio A, Yu CM. Beyond the measurement of QRS complex toward mechanical dyssynchrony: Cardiac resynchronisation therapy in heart failure patients with a normal QRS duration. Heart. 2004;90(5):479-481.

16. Wang NC, Maggioni AP, Konstam MA, Zannad F, Krasa HB, Burnett JC, Grinfeld L, Swedberg K, Udelson JE, Cook T, Traver B, Zimmer C, Orlandi C, Gheorghiade M. Clinical implications of QRS duration in patients hospitalized with worsening heart failure and reduced left ventricular ejection fraction. JAMA Journal of the American Medical Association. 2008;299(22):2656-2666.

17. Drakos SG, Terrovitis J V., Nanas JN, Charitos El, Ntalianis AS, Malliaras KG, Diakos N, Koudoumas D, Theodoropoulos S, Yacoub MH, Anastasiou-Nana MI. Reverse electrophysiologic remodeling after cardiac mechanical unloading for end-stage nonischemic cardiomyopathy. Annals of Thoracic Surgery. 2011;91(3):764-769.

18. Drakos SG, Wever-Pinzon O, Selzman CH, Gilbert EM, Alharethi R, Reid BB, Saidi A, Diakos NA, Stoker S, Davis ES, Movsesian M, Li DY, Stehlik J, Kfoury AG. Magnitude and time course of changes induced by continuous-flow left ventricular assist device unloading in chronic heart failure: Insights into cardiac 
recovery. Journal of the American College of Cardiology. 2013;61(19):1985-94.

19. Lang RM, Badano LP, Mor-Avi V, Afilalo J, Armstrong A, Ernande L, Flachskampf FA, Foster E, Goldstein SA, Kuznetsova T, Lancellotti P, Muraru D, Picard MH, Rietzschel ER, Rudski L, et al. Recommendations for cardiac chamber quantification by echocardiography in adults: An update from the American society of echocardiography and the European association of cardiovascular imaging. European Heart Journal Cardiovascular Imaging. 2015;28(1):1-39.E14.

20. Hamilton LC. Statistics with stata updated for stata 9.; 2006.

21. Vittinghoff E, Glidden D V., Shiboski SC, McCulloch CE. Regression Methods in Biostatistics. Boston, MA: Springer US; 2005.

22. Neeman T. Clinical Prediction Models: A Practical Approach to Development, Validation, and Updating. New York (NY): Springer. 2009.

23. StataCorp. STATA BASE REFERENCE MANUAL RELEASE 16 ®. StataCorp LLC. 2019.

24. Wever-Pinzon O, Drakos SG, McKellar SH, Horne BD, Caine WT, Kfoury AG, Li DY, Fang JC, Stehlik J, Selzman CH. Cardiac Recovery During Long-Term Left Ventricular Assist Device Support. Journal of the American College of Cardiology. 2016;68(14):1540-53.

25. Goldstein DJ, Maybaum S, MacGillivray TE, Moore SA, Bogaev R, Farrar DJ, Frazier $\mathrm{OH}$. Young patients with nonischemic cardiomyopathy have higher likelihood of left ventricular recovery during left ventricular assist device support. Journal of Cardiac Failure. 2012;18(5):392-395. 
26. Simon MA, Kormos RL, Murali S, Nair P, Heffernan M, Gorcsan J, Winowich S, McNamara DM. Myocardial recovery using ventricular assist devices: Prevalence, clinical characteristics, and outcomes. Circulation. 2005;112(9 SUPPL.):32-36.

27. Harding JD, Piacentino V, Gaughan JP, Houser SR, Margulies KB.

Electrophysiological alterations after mechanical circulatory support in patients with advanced cardiac failure. Circulation. 2001;104(11):1241-1247.

28. Thomas IC, Cork DP, Bhatia AK, Nayak HM, Burke MC, Moss JD. QRS complex fragmentation and survival following left ventricular assist device implantation. IJC Heart and Vasculature. 2015;7:165-169.

29. Alattar F, Imran N, Shamoon F. Fragmented QRS and ejection fraction in heart failure patients admitted to the hospital. IJC Heart and Vasculature. 2015;9:1114.

30. Katritsis DG, Siontis KC, Bigger JT, Kadish AH, Steinman R, Zareba W, Siontis GCM, Bardy GH, loannidis JPA. Effect of left ventricular ejection fraction and QRS duration on the survival benefit of implantable cardioverter-defibrillators: Meta-analysis of primary prevention trials. Heart Rhythm. 2013;10(2):200-206.

31. Chan DD, Wu KC, Loring Z, Galeotti L, Gerstenblith G, Tomaselli G, Weiss RG, Wagner GS, Strauss DG. Comparison of the relation between left ventricular anatomy and QRS duration in patients with cardiomyopathy with versus without left bundle branch block. American Journal of Cardiology. 2014;113(10):17171722.

32. Dhingra R, Ho Nam B, Benjamin EJ, Wang TJ, Larson MG, D'Agostino RB, Levy 
D, Vasan RS. Cross-sectional relations of electrocardiographic QRS duration to left ventricular dimensions: The Framingham Heart Study. Journal of the American College of Cardiology. 2005;45(5):685-689.

33. Rickard J, Baranowski B, Grimm RA, Niebauer M, Varma N, Tang WHW, Wilkoff BL. Left Ventricular Size does not Modify the Effect of QRS Duration in Predicting Response to Cardiac Resynchronization Therapy. PACE - Pacing and Clinical Electrophysiology. 2017;40(5):482-487. 


\section{Acronyms}

Atrial fibrillation (AF)

Alanine aminotransferase (ALT)

Aspartate aminotransferase (AST)

Alkaline phosphatase (ALP)

Angiotensin-converting-enzyme inhibitor (ACEI)

Angiotensin receptor blockers (ARB)

Blood urea nitrogen (BUN)

Brain natriuretic peptide (BNP)

Body surface area (BSA)

Body mass index (BMI)

Cardiac index $(\mathrm{Cl})$

Creatinine $(\mathrm{Cr})$

Heart rate (HR)

Hemoglobin $(\mathrm{Hb})$

Intra-aortic balloon pump (IABP)

Inter ventricular septal diameter (IVSD)

Left ventricular ejection fraction (LVEF)

Left ventricular end-diastolic diameter (LVEDD)

Left ventricular end-systolic diameter (LVESD)

Mechanical circulatory support (MCS)

Right atrial pressure (RAP)

Pulmonary atrial pressure (PAP)

Pulmonary capillary wedge pressure (PCWP)

Pulmonary vascular resistance (PVR)

Right ventricular stroke work index (RVSWI)

Systemic vascular resistance (SVR)

Tricuspid regurgitation (TR) 
medRxiv preprint doi: https://doi.org/10.1101/2021.09.21.21263287; this version posted September 23, 2021. The copyright holder for this preprint (which was not certified by peer review) is the author/funder, who has granted medRxiv a license to display the preprint in perpetuity.

It is made available under a CC-BY-NC-ND 4.0 International license .

Table 1. Demographics, baseline clinical characteristics, medications, labs, hemodynamic and echocardiography measures of responders and non-responders.

\begin{tabular}{|c|c|c|c|c|}
\hline Variables & $\begin{array}{l}\text { All } \\
\text { Patients } \\
(\mathrm{N}=315)\end{array}$ & $\begin{array}{l}\text { Non-Responders } \\
(n=280)\end{array}$ & $\begin{array}{l}\text { Responders } \\
(n=35)\end{array}$ & $p$ value \\
\hline Age (years), M $\pm S D$ & $56 \pm 15$ & $57 \pm 14$ & $49 \pm 20$ & 0.014 \\
\hline Race (Caucasian), n (\%) & $262(83)$ & $234(84)$ & $11(78)$ & 0.335 \\
\hline Ethnicity (Hispanic), n (\%) & $22(7)$ & $20(7)$ & $2(5)$ & 0.721 \\
\hline Male, n (\%) & $267(85)$ & $241(86)$ & $26(74)$ & 0.068 \\
\hline \multicolumn{5}{|l|}{ Clinical Risk factors } \\
\hline $\mathrm{BSA}\left(\mathrm{m}^{2}\right), \mathrm{M} \pm \mathrm{SD}$ & $2.04 \pm 0.25$ & $2.05 \pm 0.25$ & $1.96 \pm 0.23$ & 0.021 \\
\hline BMI $\left(\mathrm{kg} / \mathrm{m}^{2}\right), \mathrm{M} \pm \mathrm{SD}$ & $28 \pm 6$ & $28 \pm 6$ & $27 \pm 6$ & 0.118 \\
\hline Diabetes, n (\%) & $115(37)$ & $104(37)$ & $11(31)$ & 0.422 \\
\hline Smoking, n (\%) & $155(49)$ & $138(50)$ & $17(47)$ & 0.785 \\
\hline Alcohol, n (\%) & $132(42)$ & $117(42)$ & $15(42)$ & 0.948 \\
\hline Hypertension, n (\%) & $147(47)$ & $134(48)$ & $13(36)$ & 0.177 \\
\hline NYHA Class IV, n (\%) & $223(71)$ & $200(72)$ & $23(64)$ & 0.333 \\
\hline MCS, n (\%) & $16(5)$ & $13(5)$ & $3(8)$ & 0.351 \\
\hline IABP, n (\%) & $22(7)$ & $19(7)$ & $3(8)$ & 0.736 \\
\hline Inotropes, n (\%) & $212(67)$ & $187(67)$ & $25(69)$ & 0.771 \\
\hline AF History, n (\%) & $133(42)$ & $123(44)$ & $10(29)$ & 0.080 \\
\hline $\begin{array}{l}\text { Previous Thoracotomy, } \mathrm{n} \\
(\%)\end{array}$ & $77(24)$ & $74(27)$ & $3(8)$ & 0.014 \\
\hline Ischemic HF, n (\%) & $127(40)$ & $119(43)$ & $8(22)$ & 0.019 \\
\hline Duration of HF, (months) & $90 \pm 85$ & $96 \pm 87$ & $44 \pm 53$ & $<0.001$ \\
\hline QRSd, (ms) & $143 \pm 37$ & $145 \pm 36$ & $123 \pm 37$ & $<0.001$ \\
\hline \multicolumn{5}{|l|}{ VAD Type: } \\
\hline HeartMate2, n (\%) & $121(38)$ & $102(37)$ & $19(53)$ & \\
\hline HeartMate3, n (\%) & $17(5)$ & $14(5)$ & $3(8)$ & 0.135 \\
\hline HeartWare, n (\%) & $156(49)$ & $144(52)$ & $12(33)$ & \\
\hline Others, n (\%) & $21(7)$ & $19(7)$ & $2(6)$ & \\
\hline \multicolumn{5}{|l|}{ Medications and Labs } \\
\hline ß-blockers, n (\%) & $207(66)$ & $180(65)$ & $27(75)$ & 0.222 \\
\hline ACEI, n (\%) & $136(44)$ & $117(42)$ & $19(54)$ & 0.176 \\
\hline
\end{tabular}


medRxiv preprint doi: https://doi.org/10.1101/2021.09.21.21263287; this version posted September 23, 2021. The copyright holder for this preprint (which was not certified by peer review) is the author/funder, who has granted medRxiv a license to display the preprint in perpetuity.

It is made available under a CC-BY-NC-ND 4.0 International license .

\begin{tabular}{|c|c|c|c|c|}
\hline ARB, n (\%) & $46(15)$ & $41(15)$ & $5(14)$ & 0.935 \\
\hline Aldosterone, n (\%) & $190(61)$ & $168(61)$ & $22(61)$ & 0.957 \\
\hline Diuretics, n (\%) & $300(95)$ & $268(96)$ & $32(89)$ & 0.057 \\
\hline Platelets $\left(\times 10^{9} / \mathrm{L}\right), \mathrm{M} \pm \mathrm{SD}$ & $215 \pm 80$ & $214 \pm 82$ & $223 \pm 67$ & 0.743 \\
\hline Albumin (g/dL), M $\pm S D$ & $3.7 \pm 0.5$ & $3.7 \pm 0.5$ & $3.6 \pm 0.5$ & 0.051 \\
\hline $\mathrm{Hb}(\mathrm{g} / \mathrm{dL}), \mathrm{M} \pm \mathrm{SD}$ & $12.5 \pm 2.3$ & $12.5 \pm 2.3$ & $12.2 \pm 2.3$ & 0.286 \\
\hline Bilirubin (mg/dL), M $\pm S D$ & $1.4 \pm 1$ & $1.4 \pm 0.9$ & $1.6 \pm 1.5$ & 0.766 \\
\hline $\mathrm{ALT}(\mathrm{U} / \mathrm{L}), \mathrm{M} \pm \mathrm{SD}$ & $57 \pm 118$ & $56 \pm 118$ & $70 \pm 122$ & 0.498 \\
\hline AST (U/L), M $\pm S D$ & $43 \pm 47$ & $42 \pm 46$ & $44 \pm 57$ & 0.821 \\
\hline$A L P(I U / L), M \pm S D$ & $104 \pm 54$ & $101 \pm 52$ & $119 \pm 61$ & 0.063 \\
\hline $\mathrm{Cr}(\mathrm{mg} / \mathrm{dL}), \mathrm{M} \pm \mathrm{SD}$ & $1.4 \pm 0.6$ & $1.4 \pm 0.5$ & $1.3 \pm 0.7$ & 0.179 \\
\hline BUN (mg/dL), M $\pm S D$ & $30 \pm 16$ & $30 \pm 16$ & $27 \pm 18$ & 0.087 \\
\hline $\mathrm{Na}(\mathrm{mmol} / \mathrm{L}), \mathrm{M} \pm \mathrm{SD}$ & $134 \pm 5$ & $134 \pm 5$ & $134 \pm 5$ & 0.686 \\
\hline $\mathrm{K}(\mathrm{mmol} / \mathrm{L}), \mathrm{M} \pm \mathrm{SD}$ & $4.1 \pm 0.5$ & $4.1 \pm 0.6$ & $3.9 \pm 0.5$ & 0.065 \\
\hline BNP (pg/mL), M $\pm S D$ & $1404 \pm 1258$ & $1330 \pm 1171$ & $1902 \pm 1380$ & 0.039 \\
\hline \multicolumn{5}{|c|}{ Hemodynamic and Echocardiography Measures } \\
\hline HR (bpm) & $88 \pm 20$ & $87 \pm 20$ & $94 \pm 25$ & 0.069 \\
\hline $\mathrm{RAP}(\mathrm{mmHg})$ & $11.8 \pm 6$ & $11.9 \pm 6.1$ & $11.5 \pm 5.7$ & 0.687 \\
\hline PAP $(\mathrm{mmHg})$ & $37 \pm 10$ & $37 \pm 10$ & $35 \pm 10$ & 0.164 \\
\hline PCWP (mmHg) & $25 \pm 8$ & $25 \pm 8$ & $24 \pm 8$ & 0.594 \\
\hline PVR (dynes - sec/cm ${ }^{-5}$ ) & $3.8 \pm 2.5$ & $3.8 \pm 2.6$ & $3.3 \pm 2.2$ & 0.304 \\
\hline RVSWI (g/m²/beat) & $7.4 \pm 3.3$ & $7.4 \pm 3.4$ & $7 \pm 3.3$ & 0.281 \\
\hline $\mathrm{Cl}\left(\mathrm{L} / \mathrm{min} / \mathrm{m}^{2}\right)$ & $1.8 \pm 0.6$ & $1.8 \pm 0.5$ & $2 \pm 0.7$ & 0.120 \\
\hline SVR (dynes - sec/cm-5) & $1502 \pm 566$ & $1508 \pm 575$ & $1451 \pm 508$ & 0.721 \\
\hline LVEF (\%) & $18.1 \pm 6.7$ & $18.1 \pm 6.6$ & $17.8 \pm 7.5$ & 0.776 \\
\hline LVEDD (cm) & $6.7 \pm 1$ & $6.8 \pm 1$ & $6.4 \pm 0.9$ & 0.040 \\
\hline LVESD (cm) & $6.2 \pm 1.1$ & $6.2 \pm 1.1$ & $6.0 \pm 0.9$ & 0.048 \\
\hline IVSD (cm) & $0.96 \pm 0.24$ & $0.97 \pm 0.24$ & $0.91 \pm 0.26$ & 0.104 \\
\hline
\end{tabular}


medRxiv preprint doi: https://doi.org/10.1101/2021.09.21.21263287; this version posted September 23, 2021. The copyright holder for this preprint (which was not certified by peer review) is the author/funder, who has granted medRxiv a license to display the preprint in perpetuity.

It is made available under a CC-BY-NC-ND 4.0 International license .

Table 2. Univariate logistic regression results of selected clinical parameters. Odds ratios $(\mathrm{OR})<1.0$ indicate the odds of cardiac recovery.

\begin{tabular}{llll}
\hline Variables & OR & $95 \%$ Cl & p value \\
\hline Age & 0.968 & $0.947-0.989$ & 0.003 \\
Male & 0.487 & $0.213-1.114$ & 0.074 \\
BSA & 0.226 & $0.053-0.935$ & 0.043 \\
BMI & 0.962 & $0.902-1.021$ & 0.237 \\
Diabetes & 0.736 & $0.348-1.558$ & 0.423 \\
Hypertension & 0.612 & $0.298-1.256$ & 0.180 \\
NYHA Class IV & 0.699 & $0.337-1.448$ & 0.335 \\
MCS & 1.846 & $0.499-6.818$ & 0.358 \\
AF History & 0.507 & $0.225-1.067$ & 0.084 \\
Previous Thoracotomy & 0.252 & $0.075-0.846$ & 0.026 \\
Ischemic HF & 0.384 & $0.169-0.873$ & 0.022 \\
Duration of HF & 0.988 & $0.981-0.995$ & $<0.001$ \\
B-blockers & 1.633 & $0.739-3.611$ & 0.226 \\
ACEI & 1.624 & $0.801-3.291$ & 0.179 \\
Diuretics & 0.328 & $0.098-1.092$ & 0.069 \\
Albumin & 0.488 & $0.237-1.000$ & 0.051 \\
Bilirubin & 1.173 & $0.874-1.573$ & 0.287 \\
ALP & 1.004 & $0.999-1.012$ & 0.071 \\
Cr & 0.708 & $0.341-1.469$ & 0.354 \\
BUN & 0.982 & $0.957-1.008$ & 0.176 \\
K & 0.601 & $0.312-1.159$ & 0.129 \\
BNP & 1.000 & $1.000-1.000$ & 0.014 \\
\hline HR & 1.016 & $0.998-1.034$ & 0.072 \\
PAP & 0.975 & $0.941-1.010$ & 0.165 \\
PVR & 0.916 & $0.774-1.083$ & 0.305 \\
CI & 1.502 & $0.889-2.538$ & 0.128 \\
LVEF & 0.992 & $0.942-1.045$ & 0.776 \\
LVEDD & $0.449-0.985$ & 0.042 \\
LVESD & $0.502-1.031$ & 0.073 \\
IVSD & $0.083-1.720$ & 0.208 \\
QRSd & $0.976-0.992$ & $<0.001$ \\
\hline
\end{tabular}


medRxiv preprint doi: https://doi.org/10.1101/2021.09.21.21263287; this version posted September 23, 2021. The copyright holder for this preprint (which was not certified by peer review) is the author/funder, who has granted medRxiv a license to display the preprint in perpetuity.

It is made available under a CC-BY-NC-ND 4.0 International license .

Table 3. Bivariate logistic regression analysis to determine independent predictors of

LVAD-induced cardiac recovery. OR $<1.0$ indicate the odds of cardiac recovery.

\begin{tabular}{lllll}
\hline Variables & OR & $95 \% \mathbf{C l}$ & p value & AUC \\
\hline Age & 0.980 & $0.957-1.004$ & 0.105 & \multirow{2}{*}{0.668} \\
QRSd & 0.987 & $0.975-0.998$ & 0.022 & \\
\hline BSA & 0.222 & $0.049-0.946$ & 0.046 & \multirow{2}{*}{0.671} \\
QRSd & 0.983 & $0.972-0.993$ & 0.002 & \\
\hline Prev. Thoracotomy & 0.298 & $0.069-0.878$ & 0.053 & \multirow{2}{*}{0.695} \\
QRSd & 0.984 & $0.973-0.995$ & 0.004 & \\
\hline Ischemic HF & 0.430 & $0.175-0.949$ & 0.047 & \multirow{2}{*}{0.684} \\
QRSd & 0.984 & $0.973-0.994$ & 0.003 & \\
\hline Duration of HF & 0.990 & $0.982-0.996$ & 0.006 & \multirow{2}{*}{0.726} \\
QRSd & 0.989 & $0.977-0.999$ & 0.042 & \\
\hline Albumin & 0.498 & $0.236-1.032$ & 0.063 & \multirow{2}{*}{0.681} \\
QRS & 0.983 & $0.972-0.993$ & 0.002 & \\
\hline BNP & 1.000 & $1.000-1.001$ & 0.005 & \multirow{2}{*}{0.701} \\
QRSd & 0.982 & $0.971-0.992$ & 0.001 & \\
\hline LVEDD & 0.753 & $0.492-1.124$ & 0.177 & \multirow{2}{*}{0.680} \\
QRSd & 0.985 & $0.973-0.995$ & 0.005 & \\
\hline
\end{tabular}


medRxiv preprint doi: https://doi.org/10.1101/2021.09.21.21263287; this version posted September 23, 2021. The copyright holder for this preprint (which was not certified by peer review) is the author/funder, who has granted medRxiv a license to display the preprint in perpetuity.

It is made available under a CC-BY-NC-ND 4.0 International license .

Table 4. Multivariate logistic regression model with AUC: $0.73(p<0.001)$.

\begin{tabular}{llll}
\hline Variables & OR & $\mathbf{9 5 \%} \mathbf{C l}$ & p value \\
\hline QRSd & 0.987 & $0.977-0.998$ & 0.027 \\
Duration of HF & 0.990 & $0.983-0.997$ & 0.006 \\
Gender (male) & 0.388 & $0.160-0.943$ & 0.037
\end{tabular}


medRxiv preprint doi: https://doi.org/10.1101/2021.09.21.21263287; this version posted September 23, 2021. The copyright holder for this preprint (which was not certified by peer review) is the author/funder, who has granted medRxiv a license to display the preprint in perpetuity.

It is made available under a CC-BY-NC-ND 4.0 International license .

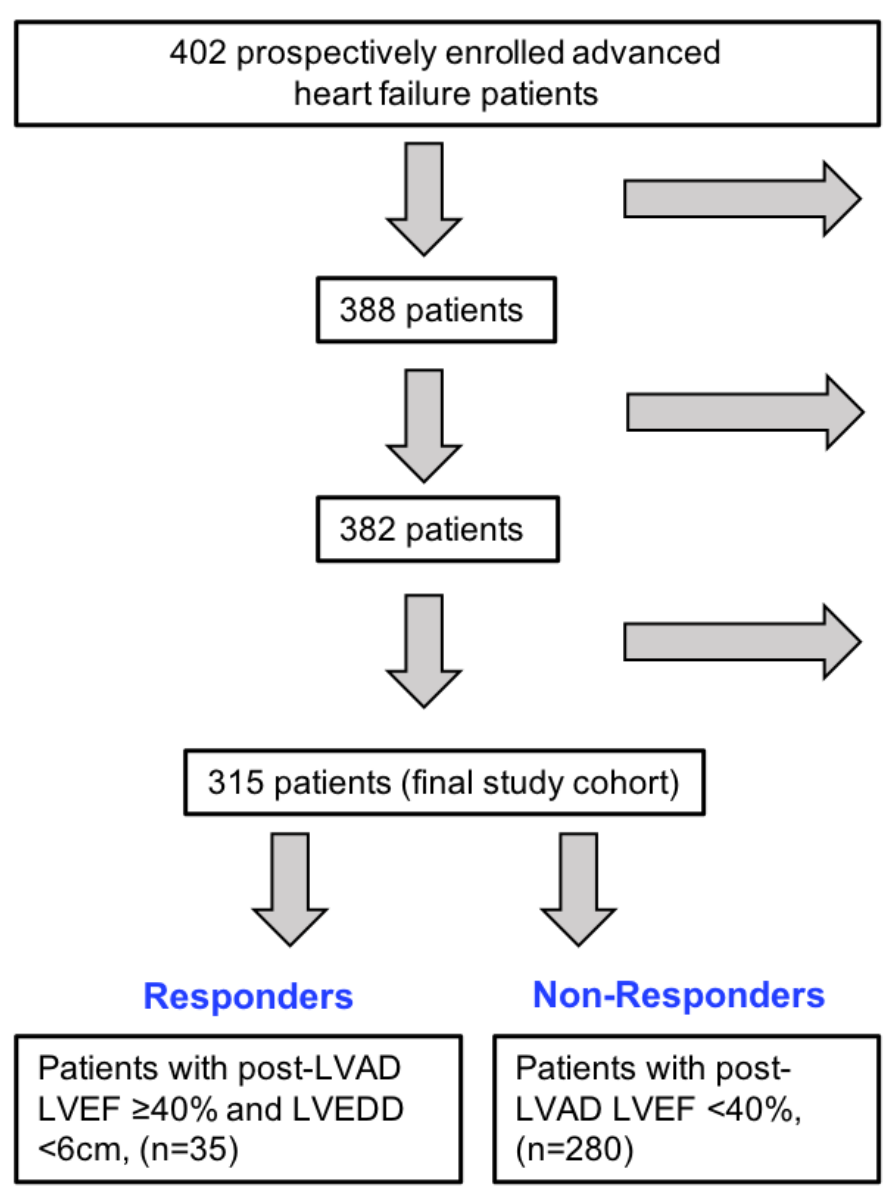

14 patients excluded due to acute heart failure etiologies $(n=12)$, hypertrophic cardiomyopathy $(n=1)$, and amyloid cardiomyopathy $(n=1)$

6 patients excluded due a preLVAD LVEF $\geq 40 \%$

67 patients excluded due to inadequate post-LVAD echo follow-up (<3 months)

Figure 1. Flowchart description of advanced HF patients undergoing LVAD implantation and included in the study. 


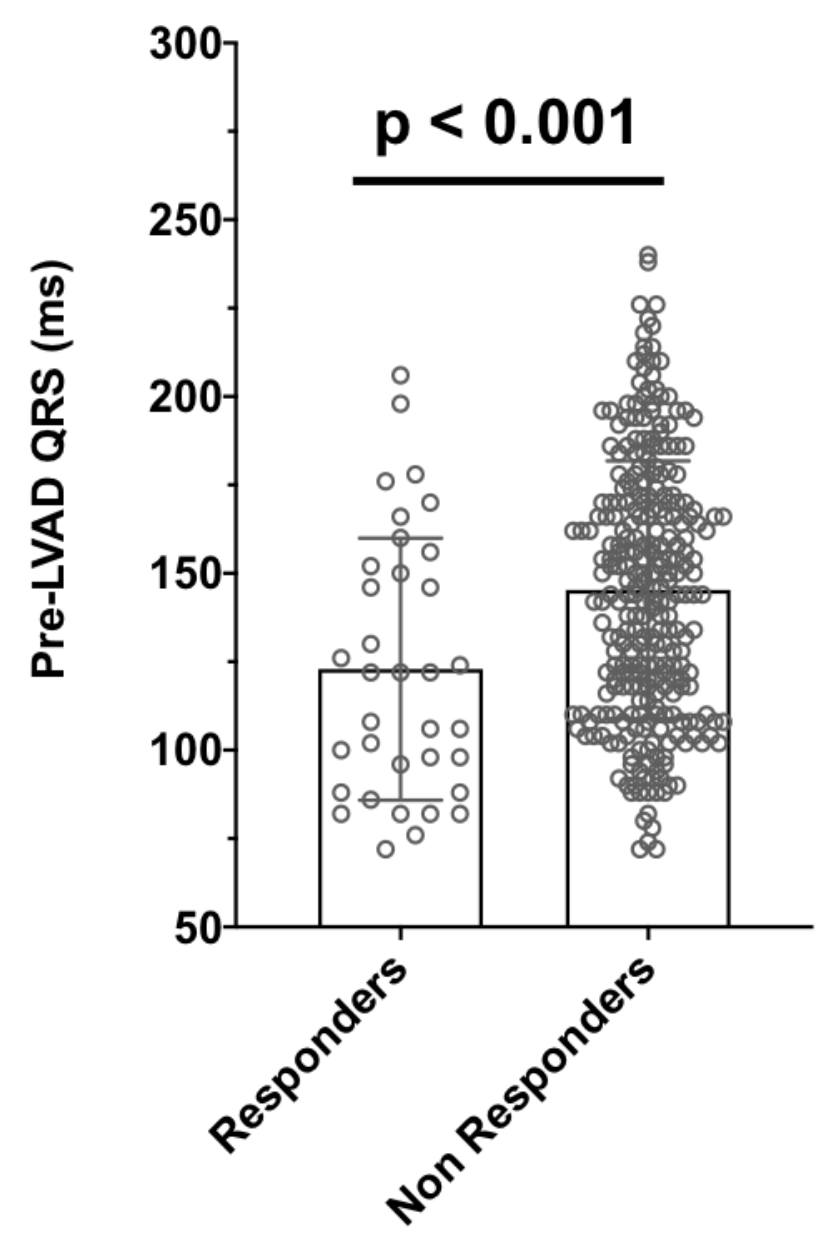

Figure 2. Baseline QRS duration in responders ( $n=35,123 \pm 37 \mathrm{~ms}$ ) in comparison to non-responders ( $\mathrm{n}=280,145 \pm 36 \mathrm{~ms})$. 
medRxiv preprint doi: https://doi.org/10.1101/2021.09.21.21263287; this version posted September 23, 2021. The copyright holder for this preprint (which was not certified by peer review) is the author/funder, who has granted medRxiv a license to display the preprint in perpetuity.

It is made available under a CC-BY-NC-ND 4.0 International license .
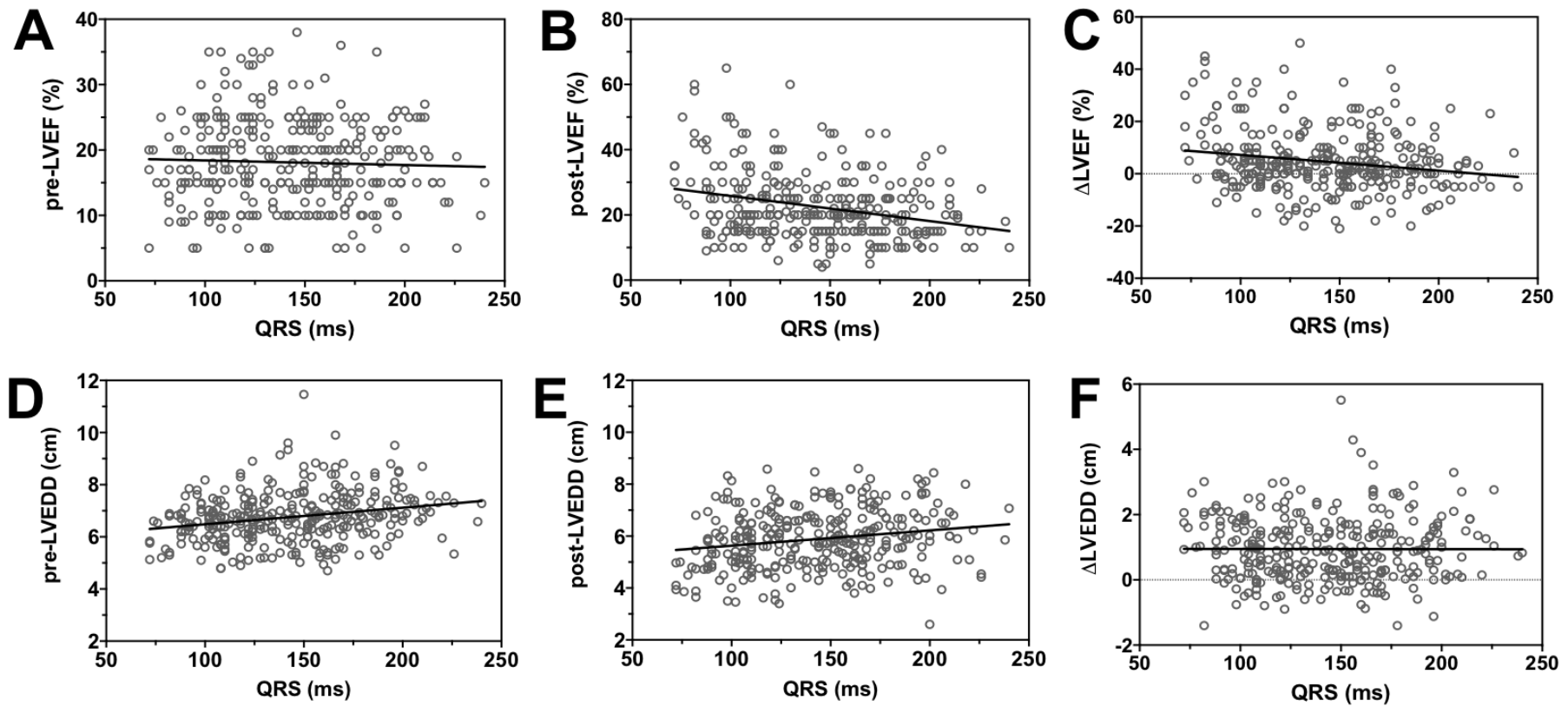

Figure 3. Impact of baseline QRS duration on pre- and post-LVAD LVEF (Top Row) and LVEDD (Bottom Row) in LVAD patients, $n=315$. (A) Correlation between QRS and pre-LVAD LVEF ( $r=-0.04, p=0.494)$. (B) Correlation between QRS and post-LVAD LVEF $(r=-0.20, p<0.001) .(C)$ Correlation between QRS and change (pre- to post-LVAD) in LVEF ( $r=-0.19, p<0.001)$. Here the negative '-' in Pearson coefficient indicates the negative slope where EF reduces with increase in QRS duration. (D) Correlation between QRS and pre-LVAD LVEDD ( $r=0.24, p<0.001)$. (E) Correlation between QRS and post-LVAD LVEDD ( $r=0.07, p=0.208)$. ( $F)$ Correlation between QRS and change (pre- to post-LVAD) in LVEDD $(r=-0.01, p=0.966)$. 

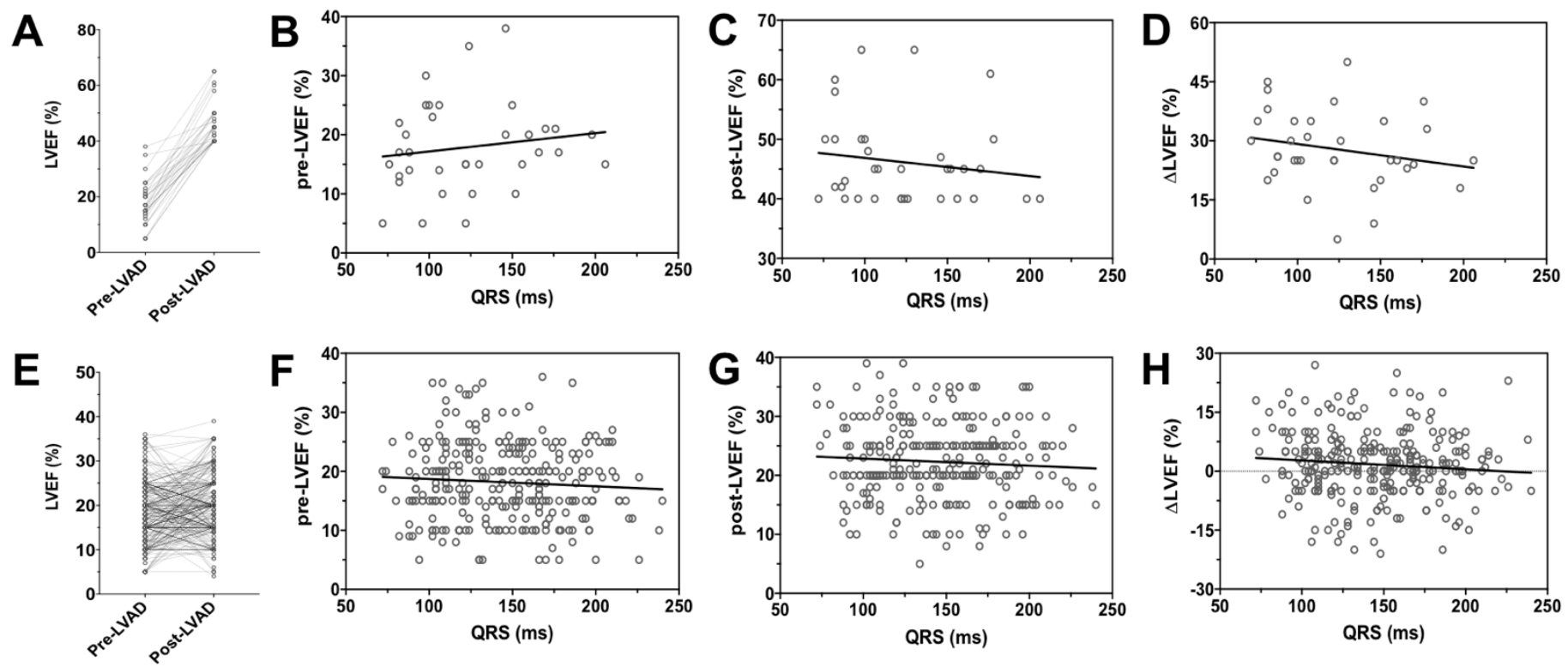

Figure 4. Impact of baseline QRS duration on pre- to post-LVAD LVEF in responders ( $\mathrm{n}=35$, Top Row) and non-responders ( $\mathrm{n}=280$, Bottom Row). (A) Comparing pre- and post-LVAD LVEF in responders (18 \pm 8 vs. $46 \pm 7 \%, p<0.001)$. (B) Correlation between QRS and pre-LVAD LVEF ( $r=0.15, p=0.386)$. (C) Correlation between QRS and postLVAD LVEF ( $r=-0.15, p=0.386)$. (D) Correlation between QRS and change (pre- to postLVAD) in LVEF ( $r=-0.22, p=0.205)$. (E) Comparing pre- and post-LVAD LVEF in nonresponders (18 \pm 7 vs. $22 \pm 6 \%, p<0.001)$. (F) Correlation between QRS and pre-LVAD LVEF $(r=-0.07, p=0.250)$. (G) Correlation between QRS and post-LVAD LVEF $(r=-0.07$, $p=0.257)$. $(H)$ Correlation between QRS and change (pre- to post-LVAD) in LVEF ( $r=-$ $0.10, p=0.104)$. The negative sign ' - ' in Pearson coefficient indicates the negative slope where change in LVEF reduces with increase in QRS duration. 

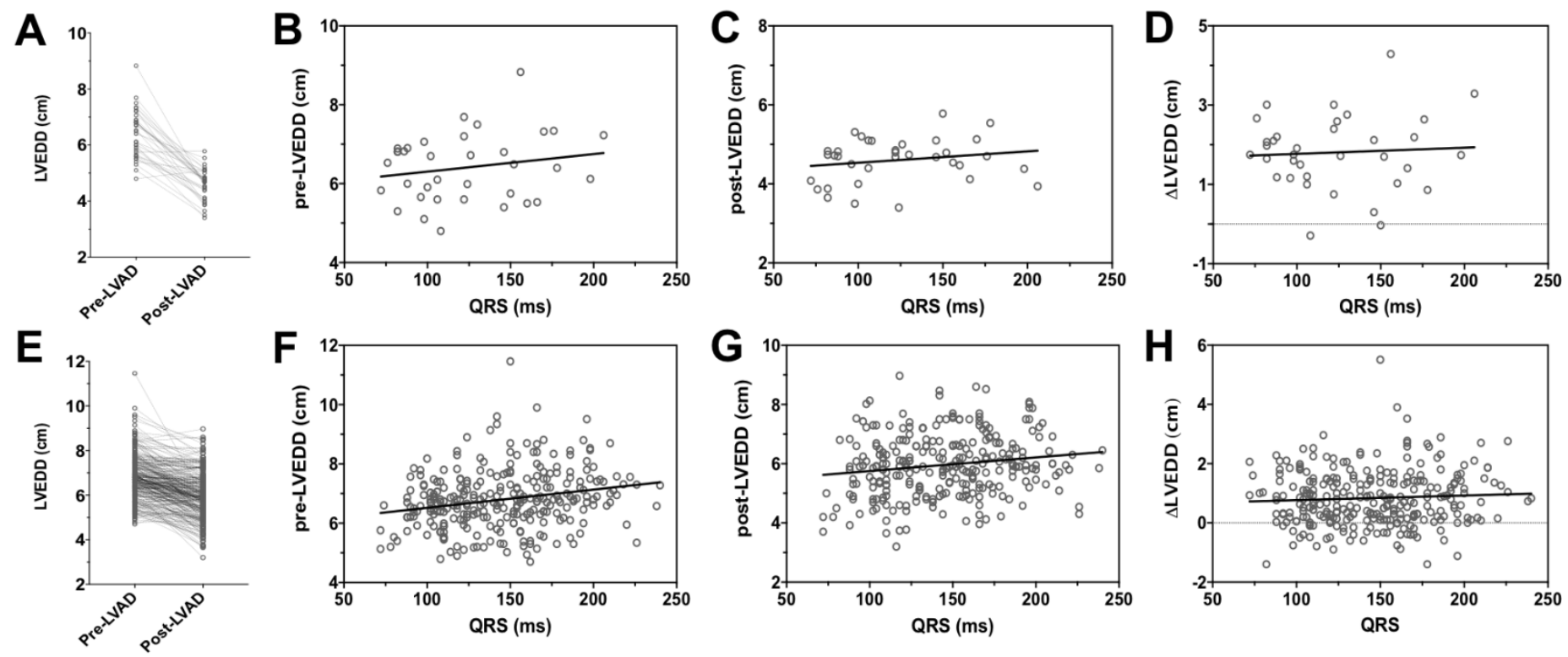

Figure 5. Impact of baseline QRS duration on pre- to post-LVAD LVEDD in responders ( $\mathrm{n}=35$, Top Row) and non-responders ( $\mathrm{n}=280$, Bottom Row). (A) Comparing pre- and post-LVAD LVEDD in responders $(6.4 \pm 0.9$ vs. $4.6 \pm 0.6 \mathrm{~cm}, \mathrm{p}<0.001)$. (B) Correlation between QRS and pre-LVAD LVEDD ( $r=0.19, p=0.268)$. (C) Correlation between QRS and post-LVAD LVEDD ( $r=0.19, p=0.273)$. (D) Correlation between QRS duration and change (pre- to post-LVAD) in LVEDD $(r=0.06, p=0.724)$. (E) Comparing pre- and postLVAD LVEDD in non-responders ( $6.8 \pm 1.0$ vs. $6.0 \pm 1.0 \mathrm{~cm}, p<0.001)$. (F) Correlation between QRS and pre-LVAD LVEDD $(r=0.23, p<0.001)$. (G) Correlation between QRS and post-LVAD LVEDD ( $r=0.16, p=0.007)$. $(\mathrm{H})$ Correlation between QRS and change (pre- to post-LVAD) in LVEDD $(r=-0.06, p=0.315)$. 


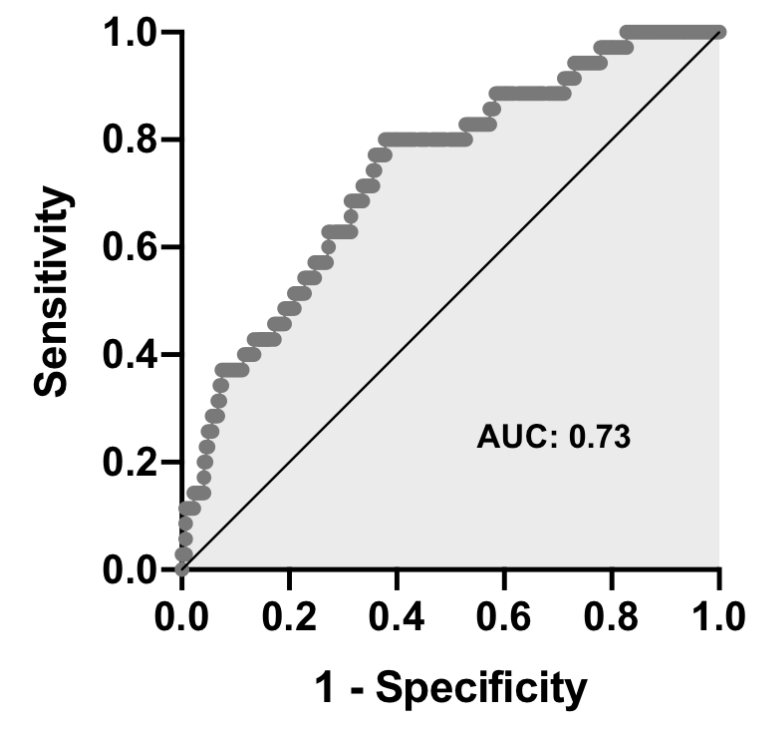

Figure 6. Multivariate logistic regression model comprised of baseline QRSd, HF duration and gender (male) shows an accuracy of 0.73 with $p<0.001$ predicting cardiac recovery within 12-months post-LVAD support. 